Catherine E. Herrold*

\title{
NGO Policy in Pre- and Post-Mubarak Egypt: Effects on NGOs' Roles in Democracy Promotion
}

DOI 10.1515/npf-2014-0034

\begin{abstract}
This article examines the Egyptian government's evolving policy toward Egypt's NGO sector and its effects on organizations' efforts to support democratic political reform. The January 25, 2011 uprisings that overthrew President Hosni Mubarak seemed to present an opportunity for Egypt's NGO sector to break free from decades of government co-optation and repression and lead Egyptian civil society's political reform efforts. NGOs did initiate democracy promotion projects immediately following the uprisings, and for a few months it seemed that NGOs would be torchbearers of political reform. By the summer of 2014, however, NGO employees were predicting the looming "death of civil society" in Egypt. Drawing upon data from over 90 interviews, this article analyzes the ways in which authoritarian adaptation, through both discourse and policy toward the NGO sector, constrained NGOs' capacities to advance political reform efforts.
\end{abstract}

Keywords: NGO policy, government-NGO relations, democratic transition, Egypt

\section{Introduction}

The January 25, 2011 uprisings that toppled Egyptian President Hosni Mubarak from his 30-year reign seemed to provide a unique opportunity for Egypt's nongovernmental organization (NGO) sector. After decades of co-optation and repression, NGOs and philanthropic foundations in Egypt suddenly had the chance to lead initiatives aimed at fostering democratic political reform. Egypt's NGO sector quickly took advantage of the political opening. Human rights organizations initiated projects related to constitutional reform, judicial reform, and transitional justice, and ramped up their ongoing human rights campaigns. Social and economic development NGOs incorporated civic education into their development

*Corresponding author: Catherine E. Herrold, Indiana University Lilly Family School of Philanthropy, University Hall, Suite 3000, 301 N. University Blvd., Indianapolis, IN 46202, USA, E-mail: cherrold@iupui.edu 
projects, working with grassroots communities to build awareness of the political process and of beneficiaries' rights as citizens. Some legan, or community-based popular committees, that sprang up during the protests registered as NGOs, and many of the youth who were at the front lines of the uprisings created NGOs as institutions through which to advance their social change goals.

This flurry of associational activity was in line with theories of democratization that credit NGOs for their roles in consolidating democratic gains made through contentious politics and preventing reversals into authoritarian rule (O'Donnell and Schmitter 1986; Diamond 1997). It also seemed to vindicate the democracy promotion strategies of Western donors, who for decades had poured funds into developing Egypt's NGO sector in the hopes that these organizations would cultivate democratic values among Egyptians and ultimately bring about a political transition.

However NGOs did not instigate or, for that matter, widely participate in the January 25th uprisings (Bremer 2011; Carapico 2012), and most of their democracy promotion efforts were short-lived. The regimes that governed Egypt after Mubarak's fall from power cracked down on the NGO sector through smear campaigns and new policy regulations, and by the summer of 2014 NGOs and foundations had become demoralized and were predicting the looming "death of civil society" in Egypt (Confidential Interview, July 9, 2014). Unlike in Latin America and Central and Eastern Europe, where NGOs were leaders in political reform processes, Egypt's NGO sector was unable to consolidate early progress and spearhead a transition to democracy.

The reasons for NGOs' failure to usher democracy into Egypt are many, and a thorough analysis is beyond the scope of this paper. Instead, the article hones in on government discourse and policy, exploring the ways in which the Supreme Council of the Armed Forces (SCAF) and the government of President Abdel Fatah el-Sisi - both holdovers from the Mubarak era - adapted to the political opening created by the January 25th uprisings and used the power of framing and the instruments of policy to constrain Egypt's NGO sector. Most of the literature that examines the role of NGOs in democratization focuses on the growth, institutionalization, and enhanced moral authority of a country's NGO sector in the democratic transition and consolidation periods (see especially O’Donnell and Schmitter 1986; Diamond 1997). This article shifts the primary focus to the government. It explores the ways in which Mubarak-era policies fragmented and weakened the NGO sector, and how the discourse and policies of the SCAF and Sisi regimes sought to consolidate government power over, and further debilitate, Egypt's NGO sector.

The article begins with a review of the literature that explores governmentNGO relationships in periods of political openings and transitions toward democracy, and then proceeds to lay out the data and methods that form the 
basis of the article's analysis. After next offering a brief overview of Egypt's NGO sector, the article analyzes how Mubarak-era policies constrained NGOs. This analysis focuses on three areas of NGO operations: activities, fundraising, and collaboration. The article then explains how NGOs briefly overcame those constraints in the wake of the January 25th uprisings. The next portion of the article turns to authoritarian adaption, exploring how the SCAF and Sisi regimes regained and consolidated control over NGOs. First, it examines how the SCAF's smear campaign sought to build public support for a government crackdown on NGOs and instill fear into the sector. Second, it examines how the government's efforts to institutionalize control through new government policies brought NGOs' efforts to promote political reform to a near standstill. The article concludes by arguing that NGOs do not, as the democratization literature suggests, automatically continue along a path of increased empowerment in the wake of a political opening. Instead, NGOs' capacity to promote political reforms may be curtailed by authoritarian adaptation.

\section{Government-NGO Relations and Democratization in Theory}

A vast literature explores government-NGO relationships in both developed and developing countries. Much of this literature views NGOs as important actors and leaders in processes of democratic transition and consolidation, serving in oppositional or adversarial roles vis-à-vis the government. Through studies of the transitions of Central and Eastern Europe (Bernhard 1993), Latin America (O’Donnell and Schmitter 1986), Southeast Asia (Kim 2000), and Africa (Bratton 1989, 1994), scholars have concluded that the formal organizations of civil society undergird successful transitions from authoritarian to democratic rule by mobilizing opposition groups and restraining state power (Diamond 1997). In the pretransition period NGOs serve as spaces of mobilization where opposition groups develop their platforms and recruit supporters. During transitions, NGOs continue to act as mobilizing structures but also pressure, prod, and advise transitional government institutions to become more transparent and accountable to citizens.

In the democratic consolidation phase, NGOs pressure the state for further democratic reforms but also enter into the business of inculcating democratic values in, and encouraging civic participation among, members (Putnam 1993; Diamond 1997; Putnam 2000; Tocqueville 2003 [1835]). NGOs are though to serve as conduits of citizen interests, voicing various groups' interests in public and political spheres. In addition, NGOs continue to act as watchdogs over the state, 
bringing to light instances of corruption and power abuse and serving as an oppositional block against a retreat into authoritarian rule.

The body of literature that explores civil society in liberalized autocracies argues that instead of serving in oppositional roles, NGOs in these states are co-opted by the government and thus lack the capacity to mobilize movements for political change. Carothers (2002) noted the "end of the transition paradigm" when he identified a growing number of formerly autocratic states that appeared to be liberalizing but instead hovered in a "political gray zone" (p. 9). These states, including many from the Middle East and North Africa, "neither moved rapidly and painlessly to democracy" nor fell "back into outright authoritarianism" (Carothers 1999, 14). Brumberg coined such states, "liberalized autocracies," characterized by a "trademark mixture of guided pluralism, controlled elections, and selective repression” (2002, 56). NGOs are allowed, and indeed encouraged, to proliferate in liberalized autocracies. But contrary to theories that see NGOs as agents of democratization, scholars of liberalized autocracies see NGOs as tools in regimes' power maintenance strategies (Bellin 1994; Wiktorowicz 2000; Brumberg 2002; Abdelrahman 2004; Albrecht and Schlumberger 2004; Albrecht 2005; Yom 2005; Heydemann 2007; Jamal 2007; Heurlin 2010; Soliman 2011).

Scholars have identified four primary mechanisms through which NGOs in liberalized autocracies bolster, rather than challenge, state power and legitimacy. First, the presence of a large NGO sector allows rulers to extend their "divide and rule" strategies beyond political and business elites (Lust-Okar 2004) and into society at large (Brumberg 2002). A sense of competition is fostered within the NGO sector so that no single organization or group of like-minded organizations becomes a threat to the ruling regime. Second, NGOs serve as the release valves of society, providing "opposition groups a way to blow off steam [... without] undermining the regime's ultimate control” (Brumberg 2003, 6). Third, NGOs offer a means through which rulers can monitor and regulate society. According to Wiktorowicz, NGOs in liberalized autocracies become "embedded in a web of bureaucratic practices and legal codes which allows those in power to monitor and regulate collective activities. This web reduces the possibility of a challenge to the state from civil society by rendering much of collective action visible to the administrative apparatus" (2000, 43). Finally, a large NGO sector allows rulers to project a guise of liberalism to international observers who view a growing civil society as a sign of greater political freedom and movement along a transition to democracy (Albrecht 2005).

Albrecht (2007) argued that in liberalized autocracies, of which Egypt under Mubarak was a quintessential model, two outcomes of a political crisis are possible: (1) fundamental change in political governance, or (2) authoritarian adaptation. The aforementioned literature on the roles of NGOs in democratic 
transition and consolidation focuses primarily on cases of fundamental change, in which countries' NGO sectors emerged from political openings as strong opposition groups and secured both the moral and legal legitimacy to champion democratic reforms. Another possibility, however, is that a regime will "learn from and adapt to the rapidly emerging challenges that the mass uprisings posed for the regime's survival" (Heydemann and Leenders 2014, 76). In what the authors coined "recombinant authoritarianism," Heydemann and Leenders suggested that regimes faced with political crisis may "reorder and reconfigure instruments and strategies of governance and [...] reshape and recombine existing institutional, discursive, and regulatory arrangements to create recognizable but nonetheless distinctive solutions to shifting configurations of challenges" (Heydemann and Leenders 2013, 7).

After the January 25th uprisings, as the democratization literature would predict, Egyptian NGOs adapted their strategies and operations to support political reform. But the government also adapted its discourse and policy toward the NGO sector, using narratives to defame NGOs and policy tools to reclaim control over the sector. Stacher (2012) defines regime adaptation as, "political change that adjust a state to changes in its environment (such as a more mobilized, complex society, weakening economic capabilities, external pressures, and so on) without giving up power or sacrificing the cohesion of elites” (p. 22). After a brief overview of the study's data and methods, the remainder of this article will explore NGO and regime adaptation in Egypt between 2011 and 2014.

\section{Data and Methods}

The data for this study are drawn from 15 months of fieldwork that took place mainly in Egypt but also included brief research trips to Jordan and Lebanon. Fieldwork was conducted from January - March 2010, May 2011-July 2012, and May - August 2014. Data are derived from 92 semi-structured interviews with staff of Egyptian development and human rights NGOs, international NGOs operating in Egypt, Egyptian philanthropic foundations, and international donors operating in Egypt, as well as leaders of Arab NGO umbrella groups and lawyers who are experts on Egypt's NGO law. All interviewees were guaranteed confidentiality due to the sensitive nature of the research topic. The article's analysis also draws upon secondary sources including NGO annual reports and websites, newspaper articles, press releases, government documents, and conference proceedings. 


\section{NGOs in Egypt: A Brief Overview}

For the purpose of this article, "NGO sector" includes associations (gamayat) and philanthropic foundations (mu'assasat). Interviewees distinguished between three types of associations, to which they referred as "NGOs": charitable NGOs, development NGOs, and human rights NGOs. The organizations included in this paper fell into the latter two categories. Development NGOs worked primarily in fields of social and economic development, while the human rights NGOs focused their efforts on advocacy and legal aid. Some human rights organizations registered not as NGOs but as law firms or civil companies in order to avoid the restrictions imposed by the law governing NGOs, Law 84 of 2002. Despite these organizations' legal status as law firms or civil companies, and in keeping with interviewees' understandings, this article includes them as part of its definition of the NGO sector.

Philanthropic foundations also registered under Law 84 of 2002. The foundations included in this study fell into two categories: community foundations and private foundations. Community foundations received funds from members of their communities and granted those funds in the same geographical communities. Private foundations received funds from members of the founder's family and/or corporation and were national in their geographic scope. Figure 1 offers a typology of Egypt's NGO sector as conceptualized in this article.
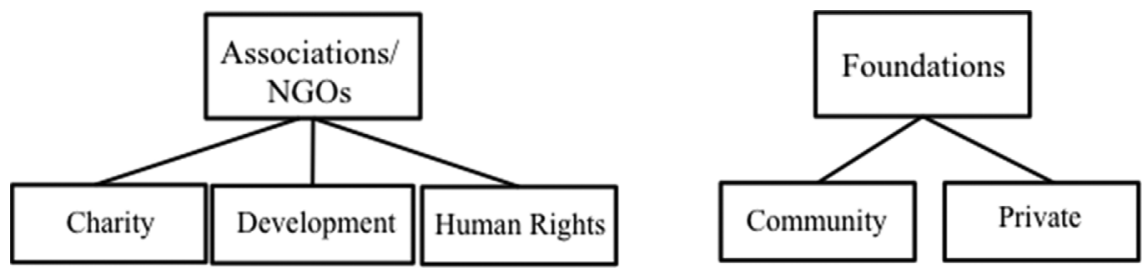

Figure 1: Egypt's NGO sector as conceptualized in this paper. Law 84 of 2002 distinguishes between associations (gamayat) and foundations (mu'assasat). Study participants referred to associations as "NGOs" and distinguished between charity, development, and human rights NGOs. They also distinguished between community and private foundations.

While precise data are unavailable, Abdou et al. (2011) estimated that in 2011 there were approximately 30,000 NGOs and foundations registered in Egypt. The vast majority of those organizations provided social welfare services. Working in fields such as education, job training, health, and other human services, these organizations sought to alleviate suffering and empower beneficiaries to enhance their lives and their communities. Only approximately 60 Egyptian 
NGOs worked explicitly on issues of human rights (Elagati 2013). Funded by international donors, these were the only NGOs in Egypt that challenged government policies prior to the 2011 uprisings.

Egypt's NGO sector experienced particularly rapid growth under the 30-year reign of President Hosni Mubarak, more than doubling in size from approximately 14,000 registered NGOs and foundations in 1993 (Sullivan 1994) to over 30,000 when Mubarak was deposed in 2011. The NGO sector's expansion coincided with state policies of economic privatization and welfare state retrenchment. In 1991, Egypt took on a structural adjustment loan through the World Bank. The loan spurred Egypt's economic privatization efforts, requiring the state to liberalize domestic prices and foreign trade, privatize public institutions, and roll back the welfare state (African Development Bank 1999; Atia 2013). In order to mitigate the effects of this economic privatization on the poor, Egypt's government increasingly looked to the NGO sector to fill in gaps left as a result of welfare state retrenchment (Fouad et al. 2005; Atia 2008; Farah 2009; Soliman 2011; Atia 2013).

At the same time that the Mubarak regime encouraged NGOs to proliferate, it also tightened control over the sector through a series of official laws and unofficial threats (Fouad et al. 2005; Soliman 2011; Atia 2013). By co-opting much of Egypt's NGO sector and relegating organizations to charitable and development work, the government used NGOs to maintain legitimacy while preventing the sector from becoming a threat to its rule. Through official laws and unofficial threats, the Mubarak regime managed to fragment, channel, monitor, and ultimately weaken potential opposition groups while simultaneously presenting a mask of liberalism to international stakeholders (Brumberg 2003; Albrecht 2005; Sa’id 2005; Farah 2009).

The primary tool that the Mubarak regime used to control Egyptian NGOs was Egypt's Law of Associations, Law 84 of 2002 (commonly referred to as the "NGO Law"). The law gave the government sweeping powers over all registered NGOs operating in Egypt and "had an immense impact on the NGO sector" (Atia 2013). Egypt's Ministry of Social Solidarity (MOSS), the government agency charged with overseeing Egypt's NGO sector, had the jurisdiction to regulate each organization's registration, governance structure, operations, fundraising, and dissolution. In addition, the State Security Investigations Service (or SSI, Egypt's security and intelligence group) harassed NGOs with discretionary questions, threats, and demands that served as informal government control mechanisms (Kausch 2009). The penalties for violating the law were severe and included imprisonment for NGO employees, fines imposed upon the NGO's leaders, and dissolution of the NGO. 


\section{NGO Policy under Mubarak}

While Law 84 of 2002 constrained virtually all aspects of NGOs' operations, government restrictions on three areas of NGO operations most profoundly affected the NGO sector's serve as an oppositional force and work for political reform. These included: (1) activities, (2) fundraising, and (3) collaboration. The remainder of this section explores how Mubarak-era NGO policies constrained these three areas of operation.

\subsection{Activities}

In order to register under Law 84 of 2002, NGOs were required to specify the fields of activity in which they would work. LaTowsky (1997) indicated that an official list of 19 activities was maintained by the government, and a lawyer confirmed this (Confidential Interview, August 7, 2014). I have never seen such a list, however Article 48 of the Executive Statute of Law 84 of 2002 indicated that approved activities included those "aimed at realizing continuing human development, whether the educational, health, cultural, or social; economic or environmental services; consumer protection; enlightenment as to the constitutional or legal rights, social defense, or human rights" (Egypt 2002a).

Article 11 of the Law 84 of 2002 expressly prohibited organizations from engaging in activities that could be deemed political or that threatened "national unity" or violated "public order or morals" (Government of Egypt 2002b). An organization that breached these provisions, which were vague and thus subject to arbitrary interpretation (Agati 2007), could, according to Article 76 of the law, face immediate dissolution and its employees could be fined and imprisoned. As a result, Egypt's NGO sector exhibited an "ingrained avoidance of all things political" (Participant, Arab Foundations Forum Conference, May 5, 2011). The director of one of Egypt's community foundations told me that the NGO sector operated within a "culture of strict government control. It is scared," she went on to say. "It thinks it is not free. Also it is charity oriented. It doesn't have the idea to lobby" (Confidential Interview, July 14, 2011).

A small number of human rights NGOs did manage to advocate for public policy change. Some registered as civil companies or as law firms in order to evade the restrictions imposed by Law 84 of 2002. The influence of these organizations was circumscribed, however, both by the watchful eye of the state and by donor influence. Funded exclusively by international donors, Egypt's human rights organizations held Cairo-based conferences and produced reports that 
were lauded by Western benefactors but remained largely unnoticed by, or out of touch with, ordinary Egyptians (Confidential Interview, August 4, 2014).

\subsection{Fundraising}

The Mubarak regime further controlled the country's NGOs by monitoring and controlling their fundraising activities. Grants from donors located in Egypt largely escaped scrutiny; recipients simply needed to declare them to the government. Article 17 of the Law, however, required NGOs seeking funds from abroad to gain approval from MOSS (Government of Egypt 2002b). The Ministry regularly failed to approve grants intended for projects that it deemed threatening, although interviewees indicated that they often did not understand what elements of their proposed projects were threatening. Technically the beneficiary organization could go to court to argue for the release of the funds, but according to an Egyptian lawyer this option was considered "a nightmare" and organizations were therefore forced to wait, often up to a year or more, for MOSS's decision (Confidential Interview, August 7, 2014).

Local grant making organizations proliferated in Egypt over the past few decades (El-Daly 2007; Ibrahim and Sherif 2008; Atia 2013), and they offered NGOs a more direct route to funding. But, like their grantees, these foundations fell under Law 84 of 2002 and thus could not provide funds for political or policy related work. "The problem is that when the Egyptian government talks about foreign funding having agendas, they forget that the organizations have no alternative sources of funds. Local indigenous funding has been dried up due to the restrictive NGO law," indicated the founder of a development NGO (Confidential Interview, February 7, 2012).

The law's restrictions on fundraising and local grant making worked in conjunction with controls on NGO activities to mold a sector in which it was virtually impossible to undertake projects that would challenge the political status quo. Even if NGOs had been willing to risk government crackdown and initiate projects aimed at promoting more democratic forms of governance, the funding required to undertake such projects would almost surely be rejected by MOSS before it reached the grant recipient.

\subsection{Collaboration}

The Mubarak regime also used the stringent legal environment to fragment Egypt's NGO sector. While Law 84 of 2002 did not explicitly ban collaboration 
among NGOs, it was widely understood within the sector that both formal partnerships and informal coordination of NGO activities would draw government suspicion and potentially elicit a crackdown (Confidential Interview, August 25, 2014). The result was a sector rife with secrecy, duplication and competition among organizations.

Interviewees stressed the sector would be better off if organizations could collaborate, but indicated with frustration that it was virtually impossible. "Everyone is a rival," explained a program officer at one of Egypt's private foundations. "We need to get people to think about others. Everyone works on their own in silence to get things done. It's hard to figure out what others are doing. There is replication at both the NGO and philanthropic levels" (Confidential Interview, January 28, 2010). "It is completely fragmented," agreed a local scholar of Egypt's NGO sector. "The regime has formed associations to use as control mechanisms, and NGOs see the risks of cooperating more than the benefits" (Confidential Interview, July 4, 2011).

In sum, prior to the January 25, 2011 uprisings, Egypt's NGO sector was fragmented and apolitical, consisting primarily of organizations that focused on socioeconomic development activities and carefully avoided engaging in issues of politics or public policy. NGO leaders were constantly aware of the watchful eye of the state and, with the exception of a small number of human rights organizations, did their best to remain in the state's good graces by filling in gaps in social welfare provision. While Egypt's NGOs provided much-needed services, state co-optation prevented them from serving as schools of democracy or as hubs of political mobilization.

\section{Post-Mubarak Euphoria and NGO Adaptation}

The January 25th uprisings seemed to present a window of opportunity for Egypt's NGOs to transform themselves from tools of the state into agents of democratization. After decades of subjugation, Egypt's NGO sector was faced with a unique opportunity to harness Egyptians' newfound drive to engage civically and politically and to lead civil society's efforts to transform Egypt into a democracy. And for a few months after Mubarak's ouster, it appeared that NGOs would indeed be torchbearers of political reform in Egypt. This section explores the ways in which Egyptian NGOs adapted to take advantage of the political opening. It analyzes this adaptation through the same three NGO operations that were the focus of the previous section: activities, fundraising, and collaboration. 


\subsection{Activities}

In the months following the January 25th uprisings, human rights organizations ramped up their work while many development NGOs embarked on projects related to politics, policy, and social change. "After the revolution we are working as if there are no constraints," explained the director of an Egyptian philanthropic foundation (Confidential Interview, July 14, 2011). The leader of an Egyptian NGO concurred. "As NGOs we used to be very careful about what we said. There was self-censorship because of the security forces. There was a shift after the revolution. It was amazing, even economic development organizations are taking on political issues. The trend after January 25th is toward advocacy and discussions regarding political systems” (Confidential Interview, February 7, 2012).

A number of NGOs included in this study focused their post-Mubarak projects on the election process. They initiated voter education and registration drives and served as elections monitors, projects that would have been futile during the rigged elections of the Mubarak era. As a staff member of one human rights organization explained, "There was a good chance to observe the electoral process in Egypt. Before the revolution there were obstacles to this but after the revolution observers were allowed" (Confidential Interview, January 31, 2012).

Other projects related to politics and policy, which had been off limits under Mubarak, were suddenly high on the agenda for many NGOs. As the director of one international foundation working in Egypt told me, "Many more organizations are interested in 'political' issues. Not party politics but policy issues, helping their members, expanding activities regarding political awareness, local governance, defense of rights, transparency and accountability" (Confidential Interview, February 22, 2011). "Political issues are involved with everything now," the director of an NGO that supports handicraft makers told me. "People have now started thinking. And in this period this is our role: to help [beneficiaries] learn about their rights, to be educated, to be stronger" (Confidential Interview, March 25, 2012).

A number of NGOs initiated workshops and training programs designed to teach local residents about democratic political processes and encourage residents to get involved in both local and national politics. "We made full-day workshops on the constitution," the director of a development NGO told me. "We asked people to submit their ideas for the [new] constitution in their own handwriting. To express themselves in the constitution was a big deal." The director went on, "Through trainings we try to transform topics of awareness. We want people to support change. We support political awareness. Not specific parties, but how to be involved, how to make choices, how to make 
change for themselves. Before the revolution we did economic and social rights and stayed far away from politics. Now they are all integrated. We do advocacy campaigns, we get people involved in political life as a whole and on local councils” (Confidential Interview, April 24, 2012).

\subsection{Fundraising}

Most Egyptian foundations were slow to respond to the January 25th uprisings, continuing to focus their grant making on social and economic development projects. International donors, by contrast, quickly ramped up their budgets for projects related to democracy and good governance. USAID, for example, raised its democracy promotion budget from $\$ 15,000$ to $\$ 65,000$ in 2011 , and began to channel many of these funds directly to NGO grantees without gaining approval from MOSS. The European Union, international private foundations, and other Western donors also increased democracy promotion budgets after the 2011 uprisings (Confidential Interviews, June 22, 2011, February 14, 2012, February 27, 2012).

Study participants often cited this increased support from abroad when talking about new opportunities that the overthrow of Mubarak presented for NGOs. "Funding has increased, mostly from foreign donors (for example, USAID, the European Union, and embassies), because they have pledged money to promote democracy in the region" (Confidential Interview, October 26, 2011), explained the director of a human rights organization. Development organizations were also eager for these additional funds. "Another opportunity is that donors are interested in Egypt, for example USAID and the European Union. There is more interest and awareness," said the director of a development NGO (Confidential Interview, March 4, 2012). Indeed, when in March, April, and May of 2011 USAID hosted information sessions on how to apply for its democracy promotion grants, "a line of people waiting to get into the session stretched down the block" (Chick 2011).

\subsection{Collaboration}

After the 2011 uprisings, NGOs began collaborate in efforts to advance political and policy reforms. "Everyone is getting together post revolution," a staff member of an Egyptian human rights organization said. Interviewees stressed that while their organizations had not previously honed skills of collaboration due to Mubarak-era regulations, they realized that their organizations would 
need to join forces in order to bring about change. "We are working together now. Our organization is convening NGOs. We are coordinating. We are in solidarity together. There is definitely coordination now, but unfortunately this came only in a time of disaster," explained the director of another Egyptian human rights organization (Confidential Interview, November 14, 2011).

This collaboration was especially strong among Egypt's human rights organizations, which quickly coalesced around efforts to change public policies. "Human rights organizations are all focused on the transition, on elections and the constitution, how to involve citizens in drafting the new constitution. We are coordinating all initiatives," (Confidential Interview, February 20, 2012). But development NGOs came together as well, particularly around advocacy campaigns to change Law 84 of 2002. "Now I am starting an advocacy campaign for Law 84. Yesterday we hosted a round table of all types of organizations. We discussed community conciliation. We refuse to consider the current draft law [under review by the SCAF]. This draft was developed before the revolution. It is not fair to have this law after the revolution. So now we begin an advocacy campaign. We will collect all parliament drafts, make comparisons, and go through Egypt to find what are the agreed articles. We will look at best practices throughout the world. For example how is 'freedom of assembly' stated in different countries? We will collect certain articles and words. We will also research law articles to find which ones all of civil society - large, small, human rights, development, charity, different geographies - agree on. Then we will prepare a draft to introduce to parliament" (Confidential Interview, February 26, 2012).

Not only did NGOs begin to partner with each other, they also attempted to work jointly with the SCAF to advance the protestors' democratic aims. "NGOs are trying to reach out to the government. They are forming coalitions to help the government shape the future," explained a staff member of a regional foundation that worked closely with its Egyptian grantees (Confidential Interview, October 24, 2011). "The important role of NGOs is providing a model," the staff member of an Egyptian NGO told me. "We can't substitute the government but we can be creative and provide a catalog and technical expertise to the government. We can serve as consultants between civil society and the government. Civil society provides ideas and technicians. We can also mobilize local communities and link the grassroots and the government. We can help the governing authorities come down to the ground. We should build bridges, create ideas and models, provide links, and catalyze" (Confidential Interview, April 2, 2012). 


\section{Government Crackdown: From Euphoria to Despair in Egypt's NGO Sector}

Thus far, the story in Egypt fits relatively well with theories of democratization. While Egypt's NGO sector did not initiate or have a strong presence in the 2011 uprisings that toppled Mubarak - indeed, even employees of human rights organizations stressed that while they personally went to the streets in protest, their organizations were not officially involved - Egyptian NGOs took advantage of a political opening and quickly took on projects related to political reform while the SCAF seemed too busy in other governance roles to notice. But while Egyptians succeeded in ousting Mubarak, it became increasingly clear that a “deep state" (Ismail 2015) composed of elements of the former regime remained in tact. Ultimately this deep state adapted right along with NGOs and cracked down on the sector in ways even harsher than under Mubarak's rule.

By the time of this writing, four governments had ruled Egypt after Mubarak's deposal: the SCAF, led by Field Marshal Mohamed Hussein Tantawi (February 11, 2011-June 30, 2012); Mohamed Morsi (June 30-2012-July 3, 2013); Adly Mansour, who was appointed Interim President by the General Command of the Armed Forces after a military coup ousted President Morsi (July 4, 2013-June 8, 2012); and former military general Abdel Fattah el-Sisi (June 8, 2014-present). All were hostile to, and sought to regain control over, Egypt's NGO sector. The remainder of this article focuses on the strategies and tactics of the SCAF and the Sisi regime. Both were holdovers from the Mubarak era and, despite a brief period of rule by Morsi, never fully relinquished power. ${ }^{1}$ The SCAF and Sisi regime adapted both government discourse and policy to curtail NGOs' democracy promotion activities. The first part of this section explores the SCAF's smear campaign intended to frame NGOs as foreign agents intent upon destabilizing Egypt. The second part of the section examines how the Sisi regime sought to institutionalize the crackdown by adding restrictions to Egypt's NGO Law.

\subsection{Smear Campaign}

The first strategic move in the SCAF's effort to curb NGOs' capacity to advance political reform was to launch a campaign to frame NGOs as tools of foreign agents. Just as Egypt's NGOs capitalized upon a newfound spirit of public

1 President Morsi was ousted after one year in power on July 3, 2013, in a military coup that reinstalled military rule. 
engagement after the January 25th uprisings, the SCAF took advantage of heightened feelings of nationalism and fear of instability as a backdrop for its campaign against NGOs. The SCAF's assault began in July of 2011, when Faiza Abou el-Naga, then Minister of Planning and International Cooperation, instructed Egypt's Justice Minister to form a fact-finding committee to investigate foreign funding of NGOs operating in Egypt. Abou el-Naga stated that the committee would be charged with "compiling a detailed report over the amount of aid given to Egyptian civil society and the funding of unlicensed international organizations working in Egypt” (Maher 2011: n. pag.). Her comments suggested that foreign aid was an intervention in Egypt's foreign affairs and that the formation of the fact-finding committee was for the good of, and indeed "at the requests of, the Egyptian public who refuse such foreign funding" (Maher 2011, n. pag.). A state prosecutor involved in the case slammed any organizations that might be found to have received foreign funds illegally as guilty of "grand treason, conspiracy against Egypt, and carrying out foreign agendas to harm Egyptian national security" (Human Rights Watch 2011, n. pag.).

In September 2011, Al-Fagar newspaper published a summary of the committee's report, listing 39 Egyptian and international NGOs that were operating without a license, 28 Egyptian NGOs that were receiving foreign funds illegally, and several other NGOs that were engaging in political activities that violated Law 84 of 2002 (Al-Fagar 2011). In December, government officials raided the offices of 17 Egyptian and international and human rights NGOs that were working on democracy promotion, seizing their computers and files and shutting down their offices. A leading judge in the investigation indicated that the raided organizations were conducting "unlicensed and illegal activities without the knowledge of the Egyptian people” (Daily News Egypt 2012, n. pag.). Contributing to the government's framing of NGOs as carrying out clandestine foreign agendas that would destabilize Egypt, the judge said that the committee "discovered that five foreign NGOs received secret money transactions from abroad" and cited as evidence of espionage and impending destabilization, "a map showing Egypt divided into four parts: Upper Egypt, the Delta, Greater Cairo and the Canal provinces” (Daily News Egypt 2012, n. pag.).

A few months later, in February of 2012, the Ministry of Justice charged 43 of these organizations' employees with receiving international funds and pursuing political and other activities that were illegal under Law 84 of 2002 (Project on Middle East Democracy 2012). Nineteen of those charged were American and, of those, 11 were residing in Egypt and banned from travel when the charges were filed. In March, after intense pressure from US officials and the posting of about $\$ 4$ million USD in bail, Egypt lifted the travel ban on the Americans and allowed 


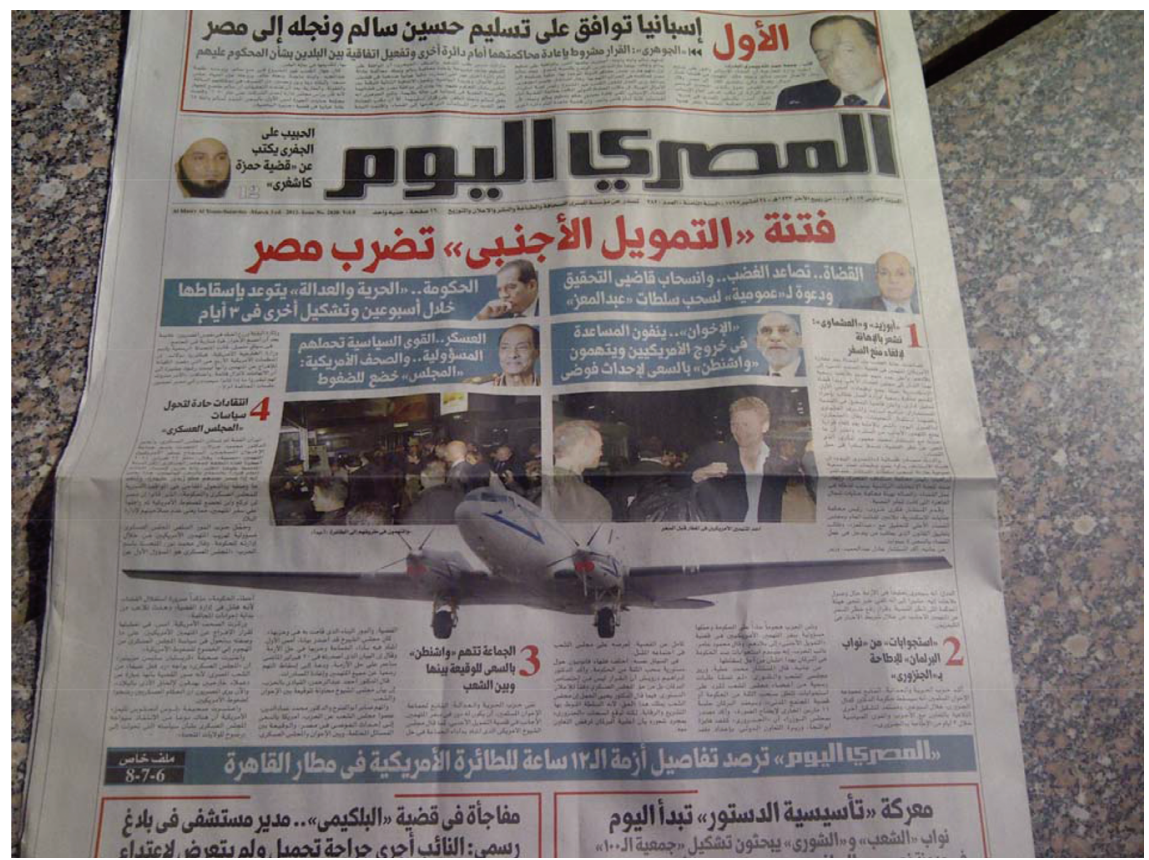

Figure 2: Front page of Al Masry Al Youm from March 3, 2012, the morning after American NGO employees who had been under travel bans were allowed to leave Egypt.

them to flee Egypt (Kirkpatrick and Myers 2012). The next morning, as shown in Figure 2, the front page of daily newspaper Al Masry Al Youm, featured a large photo of an airplane along with smaller photos of the Americans arriving at Cairo International Airport.

The message that the Americans were escaping justice was clear, and in fact led to a backlash against the SCAF (Egypt Independent 2012). But the incident also added credibility to the story that international NGO workers were meddling illegally in Egypt. Ultimately, on June 4, 2013, all 43 employees were convicted and sentenced to five years in prison (Azeem 2013).

While this public crackdown on NGOs targeted international and human rights organizations, Egyptian development organizations were also affected. The SCAF's campaign injected fear into Egypt's entire NGO sector. "There is an atmosphere of forced gaiety but there is underlying anxiety," the director of an Egyptian philanthropic foundation told me. "Everyone is getting the "no democracy [promotion]' message," the director went on to say, "and most aren't foolhardy enough to continue after getting the message" (Confidential Interview, October 22, 2011). 
The government used the media to stoke a heightened sense of nationalism and slander NGOs as foreign agents. "Many NGOs fear being hated by the Egyptian people because of American policies in the Middle East. Also NGOs fear providing access to the public, for example journalists. They distort the image of NGOs," explained a staff member of one of Egypt's human rights organizations. (Confidential Interview, January 31, 2012). The director of an Egyptian development organization concurred. "We feel sad and sorry because with the recent crisis the media dealt with it in a very bad way. They accused NGOs generally of being not faithful, spies, destroying Egypt's dignity, and interfering in politics. That's really bad, to use the media to attack NGOs" (Confidential Interview, March 5, 2012).

The campaign succeeded in making NGOs hesitant to continue to seek and accept funds from abroad. A program officer at an international aid agency indicated that, "NGOs report problems from their beneficiaries. Some won't come because the NGO is foreign funded, and thus might have a secret agenda and might try to divide the country" (Confidential Interview, February 14, 2012). A program officer at another international aid agency said that all grantees were affected, not only those working in areas of democracy promotion. "All NGOs are hesitant to take funds from us, both democracy and economic development funds," she said (Confidential Interview, February 27, 2012).

\subsection{Government Policy}

Building upon this increasing public skepticism of NGOs, the Sisi regime proposed a new NGO law that would expand the government's control and power to repress Egypt's NGO sector. Interviewees decried the draft law as even more draconian than Law 84 of 2002. "It will be much worse, like North Korea. It will be the death of civil society if they enforce it," claimed the director of an international NGO working with local NGO partners. "We have partners, local human rights organizations, whose employees have packed prison clothes so that when they are dragged to prison they don't need to wear the bug-infested prison uniforms," he went on to say (Confidential Interview, July 9, 2014). The remainder of this section analyzes the 2014 draft law again through the lenses of NGO activities, fundraising, and collaboration.

\subsubsection{Activities}

Whereas Article 11 of Law 84 of 2002 vaguely banned political activities, Article 11 in the 2014 draft law went further to specify that NGOs must operate in the fields 
of "social care, development, and awareness raising of communities" (International Center for Not-for-Profit Law 2014b). Analysts at the International Center for Not-for-Profit Law interpreted this language as an effort to "exclude or at least limit organizations that work on human rights, advocacy, and oversight" (International Center for Not-for-Profit Law 2014b). Article 11 also prohibited NGOs from "conducting field researches or surveys for projects in the field of national work without obtaining approval of the Central Agency for Public Mobilization and Statistics" (International Center for Not-for-Profit Law 2014b).

The 2014 draft law also aimed to bring human rights organizations that were registered as law firms or as civil companies under the NGO Law's jurisdiction. It required all organizations doing the work typical of an NGO to register under the law. According to Paragraph 4 of the Preamble, "It is prohibited for any entity to practice any of the activities of national associations and foundations without being subject to the provisions of this law" (International Center for Not-forProfit Law 2014b). "I can’t imagine anyone who would want to set up an NGO," the director of the Egyptian office of an international NGO said, pointing out that the restrictions on registration, activities, and fundraising constrained any organization wishing to work on human rights or advocacy. "But," he went on to say, "all entities must be registered [under the draft law] as NGOs or they will be dissolved and their employees will go to prison" (Confidential Interview, July 9, 2014). Indeed, article 80 of the draft law imposed "imprisonment for no less than one year and a fine of no less than 100,000 Egyptian pounds" upon "persons who engage in [NGO] activities ... without registering" (International Center for Not-for-Profit Law 2014b).

\subsubsection{Fundraising}

Both the 2014 draft NGO law and an amendment to Egypt's penal code imposed even tighter restrictions on foreign funding flowing to Egypt-based NGOs. Article 17 of the draft law established a Coordinating Committee composed of various government ministries and the SSI that would have the power to approve or deny all funds originating from outside of Egypt. The draft law granted the Coordinating Committee arbitrary discretion to reject an NGO's request for funding approval, and imposed penalties of imprisonment, fines, and NGO dissolution for organizations and their employees that failed to seek approval for foreign funding or comply with the Coordinating Committee's decisions (International Center for Not-for-Profit Law 2014a). In addition, on September 21, 2014 President Sisi amended Egypt's Penal Code to impose a life prison sentence on any individual requesting or receiving foreign assets with the intent 
to "harm the national interest," "compromise national sovereignty, or "breach security or public peace” (International Center for Not-for-Profit Law 2014a).

\subsubsection{Collaboration}

The government's crackdown also stifled collaborative efforts that NGOs initiated after the uprisings. As a sense of fear and caution returned, NGOs began "keeping their heads down, not wanting to be exposed" (Confidential Interview, October 22, 2011). The government's raids and investigations of NGOs, as well as the repressive language of the draft law, signaled that the government would continue its efforts to "divide and rule" (Brumberg 2002) Egypt's NGO sector. "The sector has been harassed," explained the director of one of Egypt's private foundations when we met in 2014. "It has affected all of us. We are under surveillance, watched out by the government and the intelligence. We don't know who is watching who" (Confidential Interview, June 24, 2014).

As a result of this surveillance, collaborations disintegrated and NGOs began to turn against each other (Confidential Interview, August 25, 2014). Egypt's human rights organizations were an exception: they managed to maintain their alliances remain outspoken proponents of political reform. Representatives from these organizations regularly issued joint statements, appeared together in press conferences, and lobbied the government to ease the restrictions in the draft Law of Associations. Other NGOs, though, began to inward and distrust each other.

Divisions and rivalries emerged at two levels: between different types of NGOs and between organizations of same type. The first set of rifts, between different types of NGOs, was especially pronounced between development and human rights organizations. Development NGOs began to see human rights organizations as "troublemakers" (Confidential Interview, August 25, 2014), and increasingly distanced themselves from the types of democracy promotion activities that were hallmarks of human rights NGOs. In return, human rights NGOs charged development NGOs as being too friendly with the government. "There is a huge problem in development NGOs - they have very strong relations with the government," said a program manager at one human rights organization (Confidential Interview, November 14, 2011). Human rights NGOs also criticized development NGOs for failing to maintain political reform efforts, claiming that a focus on economic development as a means of advancing Egypt was "the official argument of the Mubarak regime" and that development NGOs that adopted the same approach "don't know democracy" (Confidential Interview, July 28, 2011). 
The second set of divisions arose between organizations of the same type. In May of 2011, just three months after Mubarak was deposed, Egyptian philanthropic foundations joined their counterparts from throughout the region at the annual conference of the Arab Foundations Forum. Participants vowed to mobilize and coordinate at national and regional levels to promote change, and they agreed that their approach to promoting political reforms should be built upon "sturdy, strong alliances" (Participant, Arab Foundations Forum, May 5, 2011). By 2014, though, only 10 of the AFF's 35 members chose to renew their memberships and the organization was struggling to remain functioning (Confidential Interview, July 8, 2014). Among Egypt's foundations, any sense of cohesion dissipated. "There is no trust anymore," explained the director of one of Egypt's private foundations. "We are losing relations built on trust and transparency” (Confidential Interview, June 24, 2014).

\section{Discussion}

Immediately after the January 25th uprisings, Egypt's NGO sector responded as the democratization literature would predict and joined forces in an effort to bring about democratic political reform. But these democracy promotion initiatives were stymied by the crackdowns of post-Mubarak rulers whose discourse and policy adaptations ultimately created an environment even more hostile to NGOs.

The democratization literature that views NGO empowerment in instances of political openings along a path of increased adversarial capacity has largely overlooked the possibility of authoritarian adaptation and the constraints such adaptation may pose on NGOs' ability to sustain momentum. The case of Egypt has highlighted the importance of political context in shaping NGOs' capacity to cultivate democratic change (Berman 2003; Jamal 2007). The January 25th uprisings that ousted Mubarak toppled a dictator but failed to destroy the regime around him. Military rulers maintained power, even during the brief period when democratically elected Mohamed Morsi officially held the presidency. Just as NGOs adapted to the political opening, so too did authoritarian rulers. And as part of a strategic game, the government turned NGOs' political reform initiatives against them by framing such initiatives as anti-Egyptian and thus justifying new policies that would further repress Egypt's NGO sector.

In the summer of 2014, the director of one of Egypt's private foundations told me, "We succeeded in getting Mubarak out. But we were naïve; we thought by taking off his head we were finished. We went home. That is against democracy. 
We need partnership and engagement to finish in the right way and to not end up like Syria or Libya" (Confidential Interview, June 24, 2014). The game played between Egypt's NGO sector and the government is not likely over. The government currently has the upper hand, and it appears that in the near term new policy restrictions will continue to silence and further disable most NGOs working in areas of democracy promotion. But while death civil society in Egypt may, as one interviewee warned, ultimately transpire, it is not yet imminent. Further adaption, by both the NGO sector and the government, will occur, and both the process and results will matter for our understanding of NGOs' roles in political change.

Funding: The Charles Stewart Mott Foundation is a major sponsor of Nonprofit Policy Forum, underwriting its open access to the public. Other sponsors include the Levin College at Cleveland State University and the Association for Research on Nonprofit Organizations and Voluntary Action. This special issue was funded through a grant by the Kresge Foundation to ARNOVA.

\section{References}

Abdelrahman, M. M. 2004. Civil Society Exposed: The Politics of NGOs in Egypt. London: Tauris Academic Studies.

Abdou, E., M. Atia, N. Hussein, H. Kharas, and A. Maaty. 2011. How Can the U.S. and International Finance Institutions Best Engage Egypt's Civil Society? Washington, DC: The Brookings Institution.

African Development Bank. 1999. Arab Republic of Egypt: Structural Adjustment Loan 1991-1994 Project Competition Report. African Development Bank.

Agati, M. 2007. "Undermining Standards of Good Governance: Egypt's NGO Law and Its Impact on the Transparency and Accountability of CSOs." International Journal of Not-for-Profit Law 9:2.

Al-Fagar. 2011. "Official Report to the Prosecutor Uncovers Names and Amounts: 1.34 Billion Egyptian Pounds Given from the United States, Europe and the Gulf to Egyptian Organizations in the Last Four Months." Al-Fagr, September 26. http://pomed.org/wordpress/wp-content/uploads/2011/09/El-Fager-article.pdf.

Albrecht, H. 2005. "How Can Opposition Support Authoritarianism? Lessons from Egypt.” Democratization 12(3):378-97.

Albrecht, H. 2007. "Authoritarian Opposition and the Politics of Challenge in Egypt." In Debating Arab Authoritarianism: Dynamics and Durability in Nondemocratic Regimes, edited by 0. Schlumberger, 59-74. Stanford, CA: Stanford University Press.

Albrecht, H., and O. Schlumberger. 2004. ““Waiting for Godot”: Regime Change Without Democratization in the Middle East." International Political Science Review 25(4):371-92. 
Atia, M. 2008. "The Arab Republic of Egypt." In From Charity to Social Change: Trends in Arab Philanthropy, edited by B. L. Ibrahim and D. H. Sherif, 23-42. Cairo: The American University in Cairo Press.

Atia, M. 2013. Building a House in Heaven: Pious Neoliberalism and Islamic Charity in Egypt. Minneapolis, MN: University of Minnesota Press.

Azeem, Z. 2013. "NGO Workers Sentenced By Egyptian Court.” Al Monitor, June 10. http://www.al-monitor.com/pulse/originals/2013/06/ngo-workers-sentenced-egyptiancourt.html.

Bellin, E. 1994. "Civil Society: Effective Tool of Analysis for Middle East Politics?" PS: Political Science and Politics 27(3):509-10.

Berman, S. 2003. "Islamism, Revolution, and Civil Society." Perspectives on Politics 1(2):257-72.

Bernhard, M. 1993. "Civil Society and Democratic Transition in East Central Europe.” Political Science Quarterly 108(2):307-26.

Bratton, M. 1989. "The Politics of Government-NGO Relations in Africa." World Development 17(4):569-87.

Bratton, M. 1994. Civil Society and Political Transition in Africa. In IDR Reports, edited by Institute for Development Research: Institute for Development Research.

Bremer, J. 2011. "Egypt: Civil Society Success or Spontaneous Combustion?" Inside ISTR 19(1):1, 4.

Brumberg, D. 2002. "Democratization in the Arab World? The Trap of Liberalized Autocracy." Journal of Democracy 13(4):56-68.

Brumberg, D. 2003. "Liberalization Versus Democracy: Understanding Arab Political Reform." In In Middle East Series Working Papers, edited by Carnegie Endowment for International Peace. Washington, DC: Carnegie Endowment for International Peace.

Carapico, S. 2012. “Egypt's NGO Suspicions.” The National Interest, January 27. http://nationalinterest.org/commentary/egypts-ngo-suspicions-6416.

Carothers, T. 1999. Aiding Democracy Abroad: The Learning Curve. Washington, DC: Carnegie Endowment for International Peace.

Carothers, T. 2002. "The End of the Transition Paradigm." Journal of Democracy 13(1):5-21.

Chick, K. 2011. "Why Egypt is angry over $\$ 65$ million in US democracy grants." The Christian Science Monitor, August 12. http://www.csmonitor.com/World/Middle-East/2011/0812/ Why-Egypt-is-angry-over-65-million-in-US-democracy-grants.

Daily News Egypt. 2012. "Judge says NGOs were lawfully inspected, not 'raided'." Daily News Egypt, February 8.

Diamond, L. 1997. "Civil Society and the Development of Democracy." Advanced Study in the Social Sciences, Madrid, Spain.

Egypt Independent 2012. "Demands mount for govt to explain NGO worker travel ban." Egypt Independent, March 2.

El-Daly, M. 2007. Philanthropy in Egypt: A Comprehensive Study on Local Philanthropy in Egypt and Potentials of Directing Giving and Volunteering Towards Development. Cairo: The Center for Development Studies (CDS).

Elagati, M. 2013. Foreign Funding in Egypt after the Revolution. Arab Forum for Alternatives, FRIDE, and HIVOS.

Farah, N. R. 2009. Egypt's Political Economy: Power Relations in Development. Cairo: The American University in Cairo Press. 
Fouad, V., N. Ref'at, and S. Murcos. 2005. "From Inertia to Movement: A Study of the Conflict over the NGO Law in Egypt." In NGOs and Governance in the Arab World, edited by N. A. al-Fattah, S. B. Nefissa, S. Hanafi, and C. Milani, 202-122. Cairo: The American University in Cairo Press.

Government of Egypt. 2002a. Executive Statute of the Law on Non-Governmental Societies and Organizations. Egypt: Cairo.

Government of Egypt. 2002b. Law No. 84 of the Year 2002 on Non-Governmental Organizations (Associations and Non-Governmental Institutions). Cairo, Egypt.

Heurlin, C. 2010. "Governing Civil Society: The Political Logic of NGO-State Relations under Dictatorship." Voluntas 21:220-39.

Heydemann, S. 2007. Upgrading Authoritarianism in the Arab World. In Analysis Paper, edited by The Saban Center for Middle East Policy at The Brookings Institution: The Saban Center for Middle East Policy at The Brookings Institution.

Heydemann, S., and R. Leenders. 2013. "Authoritarian Governance in Syria and Iran: Challenged, Reconfigured, and Resilient." In Middle East Authoritarianisms: Governance, Contestation, and Regime Resilience in Syria and Iran, edited by S. Heydemann, and R. Leenders, 1-35. Stanford, CA: Stanford University Press.

Heydemann, S., and R. Leenders. 2014. "Authoritarian Learning and Counterrevolution." In The Arab Uprisings Explained: New Contentious Politics in the Middle East, edited by M. Lynch, 75-92. New York, NY: Columbia University Press.

Human Rights Watch. 2011. Egypt: Government Moves to Restrict Rights and Democracy Groups.

Ibrahim, B. L., and D. H. Sherif, eds. 2008. From Charity to Social Change: Trends in Arab Philanthropy. Cairo: The American University in Cairo Press.

International Center for Not-for-Profit Law. 2014a. Egypt Information Update: Amendments to Provisions on Foreign Funding in Penal Code. Edited by International Center for Not-for-Profit Law. Amman, Jordan: International Center for Not-for-Profit Law.

International Center for Not-for-Profit Law. 2014b. Information Update-Egypt: New Draft NGO Law by Ministry of Social Solidarity. Amman, Jordan: International Center for Not-for-Profit Law.

Ismail, S. 2015. "The Resurgence of Police Government in Egypt.” In The Arab Thermidor: The Resurgence of the Security State, edited by Project on Middle East Political Science, 63-66. Washington, DC: Project on Middle East Political Science.

Jamal, A. A. 2007. Barriers to Democracy: The Other Side of Social Capital in Palestine and the Arab World. Princeton, NJ: Princeton University Press.

Kausch, K. 2009. Defenders in Retreat: Freedom of Association and Civil Society in Egypt. In Working Paper, edited by FRIDE. Madrid: FRIDE.

Kim, H.-R. 2000. "The State and Civil Society in Transition: The Role of Non-Governmental Organizations in South Korea." The Pacific Review 13(4):595-613.

Kirkpatrick, D. D., and S. L. Myers. 2012. "U.S. Defendants Leave Egypt Amid Growing Backlash." The New York Times, March 1.

LaTowsky, R. J. 1997. Egypt's NGO Sector, a Briefing Paper. Cairo: Education for Development.

Lust-Okar, E. 2004. "Divided They Rule: The Management and Manipulation of Political Opposition." Comparative Politics 36(2):159-79.

Maher, H. 2011. "Justice minister to form fact-finding committee over NGO funding in Egypt." Ahram Online, July 12. http://english.ahram.org.eg/NewsContentP/1/16254/Egypt/Justiceminister-to-form-factfinding-committee-ove.aspx. 
O’Donnell, G., and P. C. Schmitter. 1986. Transitions from Authoritarian Rule: Tentative Conclusions about Uncertain Democracies. Baltimore, MD: The Johns Hopkins University Press.

Project on Middle East Democracy. 2012. Backgrounder: The Campaign against NGOs in Egypt. Washington, DC: Project on Middle East Democracy.

Putnam, R. D. 1993. Making Democracy Work: Civic Traditions in Modern Italy. Princeton, NJ: Princeton University Press.

Putnam, R. D. 2000. Bowling Alone: The Collapse and Revival of American Community. New York, NY: Simon \& Schuster.

Sa'id, M. Al.-S. 2005. "Civil Versus Political Culture in NGOs." In NGOs and Governance in the Arab World, edited by S. B. Nefissa, N. A. al-Fattah, S. Hanafi, and C. Milani, 55-68. Cairo: The American University in Cairo Press.

Soliman, S. 2011. The Autumn of Dictatorship: Fiscal Crisis and Political Change in Egypt under Mubarak. Stanford, CA: Stanford University Press.

Stacher, J. 2012. Adaptable Autocrats: Regime Power in Egypt and Syria. Stanford, CA: Stanford University Press.

Sullivan, D. J. 1994. Private Voluntary Organizations in Egypt: Islamic Development, Private Initiatives, and State Control. Gainesville, FL: University of Florida Press.

Tocqueville, Ad. e. 2003. Democracy in American and Two Essays on America, 1835. London: Penguin Books. Original edition.

Wiktorowicz, Q. 2000. "Civil Society as Social Control: State Power in Jordan." Comparative Politics 33(1):43-61.

Yom, S. L. 2005. "Civil Society and Democratization in the Arab World." The Middle East Review of International Affairs 9 (4):14-33.

\section{Bionote}

\section{Catherine E. Herrold}

Catherine E. Herrold is an Assistant Professor at the Indiana University Lilly Family School of Philanthropy. She holds a PhD from Duke University, an MBA from the Vlerick Leuven Gent Management School, an MSc from the London School of Economics and Political Science, and a BA from Mount Holyoke College. Herrold's work explores the role of civil society organizations in processes of democratic transition and consolidation, with a particular focus on the Middle East. 